\title{
Modern state and perspectives of applying ground fresh water for water supply of population
}

\author{
I. S. Zektser ${ }^{1}$ \\ Received 29 February 2008; accepted 22 March 2008; published 26 April 2008.
}

[1] A tendency to a greater use of ground waters for water supply is currently observed. This is explained by the well known fact that ground waters as a water source have a number of advantages compared to the surface waters. Natural resources are indicators of renewal of ground waters reflecting their main peculiarity as a renewed resource. The long-term value of ground water source minus evaporation is equal to the underground sink, therefore in the regional estimates, natural resources of ground waters are frequently expressed by the annual mean or minimal absolute values of underground sink (in liters per second from $1 \mathrm{~km}^{2}$ ). The main methods of regional estimates of natural resources, their advantages and restrictions (method of genetic division of rivers hydrographs over a long-term period, estimates of the variations in the low runoff between hydrometric lines, hydrodynamic method of calculation of flow discharge including modeling, method of water balance of source regions or reload of ground waters, estimate of infiltration source of ground waters based on the regime of their levels) are described in this presentation. The choice of the specific method for calculating water resources depends on the objectives, goals, and scale of investigation and on the hydrological, hydrogeological, and anthropogenic conditions of the estimated territory. INDEX TERMS: 1806 Hydrology: Chemistry of fresh water; 1829 Hydrology: Groundwater hydrology; 1831 Hydrology: Groundwater quality; 1832 Hydrology: Groundwater transport; KEYWORDS: Water supply, natural resources, operation resources, estimates and mapping, pumping of ground waters.

Citation: Zektser, I. S. (2008), Modern state and perspectives of applying ground fresh water for water supply of population, Russ. J. Earth. Sci., 10, ES3006, doi:10.2205/2007ES000265.

\section{Introduction}

[2] In this presentation we consider the Russian and international experience of regional estimates and mapping of the natural resources of ground fresh waters.

[3] A tendency to a greater use of ground waters for water supply is currently observed. This is explained by the well known fact that ground waters as a water source have a number of advantages compared to the surface waters. First of all, the quality of ground waters is usually high and they are better protected from pollution and infection; they are less subjected to seasonal and long-term fluctuations and in the majority of cases their use does not require expensive works for purification.

[4] Usually, ground waters of high quality can be found in the immediate vicinity of the consumer. In a number

\footnotetext{
${ }^{1}$ Institute of Water Problems, Russian Academy of Sciences, Moscow, Russia,

Copyright 2008 by the Russian Journal of Earth Sciences. ISSN: 1681-1208 (online)
}

of regions, where surface waters are lacking, water supply of the population and industry is completely based on the use of ground waters. It is important to keep in mind the economical aspect of the problem (constructions of groundwater intake) can be carried out gradually as the demand for water increases, while construction of large hydrotechnical constructions for intake of surface waters usually requires simultaneous investments. These advantages and especially lesser vulnerability of ground waters to pollution determined wide use of ground waters for water supply.

\section{Main Principles of Estimating and Use of Ground Water Resources}

[5] A number of classifications exist for denoting the amounts of ground water. In the major part of them there is a difference between resources and reserves. Notion "resources" was introduced to hydrogeology by Academician F. P. Savarensky.

[6] He based the necessity of introduction of this notion 
for ground waters by the fact that ground waters do not have permanent reserves as other mineral resources because they are permanently renewed in the process of general water cycle. In the use of ground waters it is frequently needed to take into account not only the volume occupied by ground waters in the given basin or water layer but to know the inflow of ground waters. Therefore, F. P. Savarensky considered that it would be more correct to speak not about the reserves of ground waters but about their resource understanding this term as their supply (feeding) and consumption, while term "reserves" is related only for the amount of waters, which is located in the given basin (or water bearing layer) not depending on its capacity. The capacity of water bearing layer and the reserves of ground water in this layer cannot be large, but the productivity of this layer can be high if it is provided with supply. On the contrary, a basin of ground waters can possess large size but annual supply of water into the layer can appear small.

[7] Let us mention one important peculiarity of ground waters related to the estimate of perspectives of their use. This is the fact that the possibility of pumping of ground waters depends not only on the amount of water contained in the layer and supplied to the layer in the natural conditions but also on the filtration properties of water bearing rocks determining the resistance to the spreading of ground waters to the water intake structures.

[8] According to the data of the European Commission on Economy, ground waters are the main source of the urban economical and drinking water supply in the majority of European countries. Water supply of such large European cities (with the population of approximately one million people and greater) as Budapest, Vienna, Hamburg, Copenhagen, Munich, Rome are completely or almost completely based on ground waters, while in such cities as Amsterdam, Brussels, and Lisbon ground water cover more than a half of the total water consumption.

[9] At the same time, the use of ground waters as the source of full-scale centralized water supply has a number of strong restrictions. In many cases, daily provision of large and largest cities with ground waters at the amounts of hundreds of thousand and even millions of cubic meters is not a real goal owing to the limited resources of ground waters in relation to the necessity of creating a system of hundreds or even thousands of water intake wells on a large territory, whose construction and operation requires enormous assignments.

[10] There is another very important aspect, which should be always kept in mind in the solution of the problem of ground water use. They are tightly related to the other components of the environment. Any variations, for example, in the amount of the atmospheric precipitation inevitably cause variations in the regime, resources, and quality of ground waters. On the contrary, variations in the ground waters lead to variations in the environment. Intense pumping of ground waters by concentrated water intake systems can lead to inadmissible decrease in the surface sink, subsidence of the earth's surface, depression of vegetation related to ground waters, and activation of karst processes. Intake of ground waters can entrain mineralized waters from deep water bearing levels, which are not applicable for drinking, while in the coastal regions the inflow can include saline sea waters. All these facts should be taken into account in the planning of ground water use.

[11] Estimate of natural and operation resources of ground waters is the practice of hydrogeological studies. Natural resources (dynamic reserves) characterize the amount of ground water supply due to infiltration of atmospheric precipitation, absorption of rivers discharge and overflow from other water bearing layers, which form a total amount of the discharge of the flow and thickness of water layer transported to the level of ground waters. Thus, natural resources are indicators of ground water renewal reflecting their main peculiarity as a replenished mineral.

[12] A strict water legislation exists in Russia (as well as it was in the USSR) and in a number of other countries. According to this legislation, fresh ground waters of high quality should be first of all used for economical and drinking water supply. Only in those regions, where estimated resources of ground waters are sufficient for satisfying the existing and perspective requirements in water of drinking quality it is possible to use fresh ground water for other purposes (including irrigation) not related to drinking water supply of the population with the permission of nature protection bodies. It is our opinion that such legislation is principally correct. We should use surface waters to the requirements not related to drinking water supply. It can be sometimes more expensive than the use of ground waters, but we should do this first of all to conserve fresh ground waters for our children and grandchildren.

[13] The plans of ground water use should take into account the fact that protection of different water bearing layers from pollution is not the same.

[14] Pressure water layers overlaid by poorly penetrable clayey layers are practically completely protected from the penetration of contaminants from the surface. In this case, pollution can be related only with unsatisfactory technical state of intake and prospecting wells. Spring waters in foothill and mountainous regions are reliably protected from pollution in the cases when no industrial activity is held in the regions of their supply. Ground waters of first water bearing layers from the surface are much worse protected especially in river valleys where ground waters are tightly related to surface waters, and inflow of surface polluted waters occurs during intake of ground waters. However, even in these cases, protection of ground waters is much greater than river waters because self-purification occurs during the propagation of polluted waters in the column of rocks. However, in all cases where it is possible reliably protected waters from deep pressure levels and spring waters are more preferable.

\section{Peculiarities of the Formation and Distribution of Natural Resources of Ground Waters}

[15] In the last decades, important investigations of regional estimates and mapping of natural resources of ground waters and underground sinks in individual large regions were carried out in a number of countries. As a result 
of these investigations, charts of underground sinks were contrived and published, among which, we name, first of all, the charts of underground sink of the USSR territory on scale 1:5000000 (1964) and 1:2500000 (1977), chart of underground sink of Central and Eastern Europe on scale 1:1500000 (1982), and World chart of hydrogeological conditions and underground sink on land on scale 1:10000000 (1999). Charts of larger scale were contrived for specific artesian basins and hydrogeological structures.

[16] The distribution of the main quantitative characteristics of natural resources of ground waters over the territory of regions is characterized by strong inhomogeneity and differentiation by the main geological structural elements and landscape climatic zones [Vsevolozhsky, 1983; Dzhamalov, 1973; Zektser, 2001]. The most general regularity is the different character of the distribution of underground sink parameters within platform (plane) territories and mountainous folded constructions when the variations in the values of long-term absolute values range from less than 0.1 to $6.0-6.8 \mathrm{l} \mathrm{s}^{-1}$ and from 0.1 to $30-50 \mathrm{l} \mathrm{s}^{-1}$ over $1 \mathrm{~km}^{2}$, respectively. In the territory of the Former Soviet Union, more than $55 \%$ of the total volume of underground sink is formed within mountainous folded regions, approximately $42 \%$ correspond to vast spaces of plates (Russian, West Siberian, Turan), and only $3-4 \%$ of the total underground sink falls on the territory of crystalline shields.

[17] In the mountainous folded regions, the distribution of underground sinks is determined mainly by sharp variations in the types of geofiltration media and orographic increase in precipitation with increasing altitude. For example, high values of the absolute values of underground sink in Caucasus, Carpathians, and Balkans, are caused by wide spreading of penetrable fissured rocks in the mountainous folded constructions and highly penetrable psephitic sediments in depressions between mountains, which forms favorable conditions of ground water supply together with deep erosion broken topography and large amount of the atmospheric precipitation [Fidelli, 1980].

[18] The role of ground waters in the formation of water balance and water resources of the regions is characterized quantitatively by the coefficients of underground sinks and coefficients of underground supply of rivers.

[19] The coefficient of underground sink is the ratio of underground sink to atmospheric precipitation. The coefficient shows, what part of the atmospheric precipitation (usually in percent) is spent on ground water supply. Within the territory of one country, this coefficient is on the average equal to $9 \%$ and varies from $1 \%$ and less to $50 \%$ and greater. The main peculiarities of the distribution of coefficients of underground sink are determined by the influence of a complex set of natural factors, the main among which is the ratio of the atmospheric precipitation to evaporation, and the composition and thickness of the rocks in the aeration zone.

[20] Latitudinal zonality is a general feature of plane territory: coefficients of underground sink decrease from northwest to southeast from $10-20 \%$ in the zone of excessive moisture to $1 \%$ and less in the steppe and semi-desert regions. In a number of regions this regularity is distorted by anomalies: mainly by an increase in the coefficients of underground sink.
[21] Ground waters are non-uniformly used in the territory of the Russian Federation. Most widely they are used in Bryansk, Vladimir, Tver, Kaluga, Orel, Smolensk, Tula regions, Marii-El and Mordoviya republics, Belgorod, Voronezh, Kursk, Lipetsk, and Tambov regions, Krasnodar territory, Kabardino-Balkar, Chechen, Ingush, and North Osetia republics, Orenburg region, Bashkortostan, Altai territory, and Gornyi Altai republic, Tomsk, Chita regions, Krasnoyarsk territory, Buryatia republic, Amur, Kamchatka, and Sakhalin regions. The proportion of ground water use in all these regions ranges from 70 to $100 \%$. Ground waters are poorly used in Novgorod, Archangelsk, Murmansk, Kostroma, Yaroslavl, Astrakhan, Omsk regions, in Karelia republic, where their proportion ranges from 3 to $20 \%$ [Yazvin and Zektser, 1996].

[22] At present, more than $60 \%$ of the cities in the Russian Federation have centralized sources of ground water supply. Let us consider in more detail the structural of economical drinking water supply in the largest cities of Russia (with a population greater than 250 th. people). Water supply of 34 of the total 77 such cities (44\%) is performed mainly from the surface water sources (more than 90\%), 24 cities (31\%) are supplied with drinking water mainly (90\%) by ground waters. The rest 19 cities (25\%) have mixed sources of water supply [Zektser, 2001].

[23] Non-uniform use of fresh ground waters in the territory of the Russian Federation is related, first of all, to the peculiarities of hydrological and hydrogeological conditions determining the value of prognostic exploitation reserves of ground waters and possibilities of their replenishing both in the natural and distorted conditions.

\section{Conclusions}

[24] In general, the perspectives of using ground waters first of all for economical and drinking water supply of the population in the Russian Federation can be considered quite optimistic. The estimates demonstrated that Russia possesses high forecasted resources of ground waters, whose total amount is approximately $300 \mathrm{~km}^{2} \mathrm{yr}^{-1}$. The operational reserves of prospected fields are of the order of $30 \mathrm{~km}^{2} \mathrm{yr}^{-1}$; approximately $20 \mathrm{~km}^{2} \mathrm{yr}^{-1}$ of these reserves are ready for industrial development. At the same time, the total intake of ground waters does not exceed $14 \mathrm{~km}^{2} \mathrm{yr}^{-1}$ including approximately $2 \mathrm{~km}^{2} \mathrm{yr}^{-1}$ used in the mines and open cast mines for water flooding. Approximately $8.9 \mathrm{~km}^{2} \mathrm{yr}^{-1}$ are used for economical drinking water supply, industrial technical water supply takes $7.7 \mathrm{~km}^{2} \mathrm{yr}^{-1}$, and irrigation of land uses $0.4 \mathrm{~km}^{2} \mathrm{yr}^{-1}$.

[25] It is seen from the figures presented here that intake of ground waters can be increased strongly, which is stated in the Federal Purposeful Program "Provision of the Russian Population with Drinking Water".

[26] The tendency for maximal possible use of ground water for drinking water supply of the population especially related to the cases of unexpected (emergency) pollution of surface water sources should currently become determining in the general strategy of increasing reliability of the systems 
of economical drinking water supply. This strategy should be directed to mandatory participation of reliably protected ground waters in the water supply systems. In those cases when cities and towns are currently provided by surface waters or ground waters that are insufficiently protected from pollution it is necessary to enhance efforts for total transferring of the systems of drinking water supply to reliably protected ground waters or if it is not possible to compulsory existence of the source based on reliably protected ground waters in the system of water supply that satisfies $25-30 \%$ of the requirements in the water of drinking quality or to the development of an autonomous source of dinking water supply.

[27] Irregular distribution of the resources, different degree of protection of individual water bearing layers from pollution, existence of hydrogeochemical provinces with increased content of separately normalized components in ground waters, possible pollution and depletion of exploitation reserves of ground waters related to economical activity, possible negative influence of intake of ground waters on other components of the natural environment determine the necessity of the individual approach to the solution of the problem of ground water use in each specific case. The main problem is in the correct formulation of the amount of water of required quality, which can be taken from a water bearing layer during the specific time of estimation without damaging the environment (including ground waters) or diminishing this damage to the minimum by means of special nature protection actions).

[28] The concept of "rational use" is based precisely on the combination of reasonable ground water intake and observing the norms of their quality. Rational use of ground waters is recommended to understand as economically reasonable exploitation of water that provides protection from pollution and depletion of their operation reserves and makes possible preserving the surface water reserves and ecological conditions at the given level.

\section{References}

Yazvin, L. S., and I. S. Zektser (1996), Resources of fresh waters in Russia: their modern state, perspectives of application, objectives of research, Water Resources, 23(1), 24.

Vsevolozhsky, V. A. (1983), Ground sink and water balance of platform, 167 pp., Nedra, Moscow.

Zektser, I. S. (2001), Ground waters as a component of the environment, 327 pp., Nauchny Mir, Moscow.

Dzhamalov, R. G. (1973), Ground sink of Tersk-Kuma artesian basin, 95 pp., Nauka, Moscow.

Fidelli, I. F. (1980), Principles and methods of regional estimates of underground sink, in Scientific basis of research and protection of ground waters, Pt. 1, p. 14, MGU, Moscow.

I. S. Zektser, Institute of Water Problems, Russian Academy of Sciences, Moscow, Russia (zektser@aqua.laser.ru) 